\title{
Suicide mortality data from the Italian police during the COVID-19 pandemic
}

\author{
Sergio Garbarino ${ }^{1,2^{*}} \mathbb{0}$, Michele Fornaro ${ }^{3}$, Rita Messina ${ }^{1}$, Maurizio Pompili ${ }^{4}$ and Fabrizio Ciprani ${ }^{1}$
}

\begin{abstract}
Suicide is a major public health issue worldwide, with about 880,000 dying annually for such a cause. The COVID-19 pandemic has led to severe social disruption both from health and economic standpoints. Law enforcement personnel have been significantly involved in helping to face the many difficulties due to the pandemic. Police officers have been subjected to further stress from managing social restrictions imposed by governments to contain the pandemic. The Italian State Police steadily approximate 100,000 people aged 25-65 years: 14 subjects (mean age 43.64 years) died by suicide in 2015, 7 (mean age 47.5 years) in 2016, 13 (mean age 45.62 years) in 2017, 10 (mean age 48.1 years) in 2018, 18 (mean age 46.78 years) in 2019, and 12 (mean age 52 years) in 2020. Our records excluded significant changes in suicide incidence rate within 2015-2020 (till December 2020). However, the COVID-19 pandemic spread faster in Italy than in other regions, meaning that the Italian State Police possibly faced prolonged, intense stress. Suicide prevention, therefore, remains a priority, especially during this difficult time.
\end{abstract}

Keywords: Suicide, Police officers, COVID-19, Prevention

\section{Background}

Suicide is a major public health issue worldwide, with about 880,000 dying annually for such a cause. It is a multifactorial phenomenon with various variables contributing to the precipitation of one individual wishing to die. The COVID-19 pandemic has led to severe social disruption from health and economic standpoints and increased prevalence of depression symptoms, assessed using the Patient Health Questionnaire-9, in the US adults more than threefold $8.5 \%$ before COVID-19 to $27.8 \%$ during COVID-19 [1]. Several reports indicated the need to be vigilant during the worldwide health emergency for a possible increase in mental health problems [2] and suicide deaths [3, 4]. Law enforcement personnel have been significantly involved in helping to face the many difficulties due to the pandemic. There is, therefore, the need to

*Correspondence: sgarbarino.neuro@gmail.com

${ }^{2}$ Department of Neuroscience, Rehabilitation, Ophthalmology, Genetics and Maternal/Child Sciences (DINOGMI), University of Genoa, Genoa, Italy

Full list of author information is available at the end of the article explore if suicide rates among police officers changed as a result of the pandemic.

At this time, results regarding suicide rates in the general population are still mixed [5]. According to a recent report by Leske et al. [6], no overall change in Queensland's suspected suicide rate since the declaration of a local public health emergency (PHED) occurred from January 29 up until late August 2020. This study is prime, since it is the first to consider pre-COVID trends in suicide mortality. Sakamoto et al. [7] explored suicide rates in Japan during 2020. They found that compared with previous years, suicide rates in Japan in 2020 increased in October and November for men and in July through November for women.

Police officers have been subjected to further stress from managing social restrictions imposed by governments to contain the pandemic. While information about the mortality rates due to suicide among people actively serving in a national police corps is rarely released to the public, we can disclose the rates of suicide among the Italian State Police during 2015-2020.

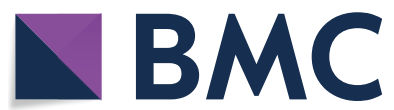

(c) The Author(s) 2021. This article is licensed under a Creative Commons Attribution 4.0 International License, which permits use, sharing, adaptation, distribution and reproduction in any medium or format, as long as you give appropriate credit to the original author(s) and the source, provide a link to the Creative Commons licence, and indicate if changes were made. The images or other third party material in this article are included in the article's Creative Commons licence, unless indicated otherwise in a credit line to the material. If material is not included in the article's Creative Commons licence and your intended use is not permitted by statutory regulation or exceeds the permitted use, you will need to obtain permission directly from the copyright holder. To view a copy of this licence, visit http://creativecommons.org/licenses/by/4.0/. The Creative Commons Public Domain Dedication waiver (http://creativecommons.org/publicdomain/zero/1.0/) applies to the data made available in this article, unless otherwise stated in a credit line to the data. 
The Italian State Police steadily approximate 100,000 people aged 25-65 years: 14 individuals (males $=13$, females $=1$; mean age $=43.64$ years) committed suicide in the year 2015. Correspondingly, 7 people (males $=7$, females $=1$; mean age $=47.5$ years) in $2016 ; 13$ people (males $=13$, mean age $=45.62$ years) in $2017 ; 10$ people (males $=10$, mean age $=48.1$ years) in 2018; 18 people (males $=16$, females $=2$, mean age 46.78 years) in 2019, and 12 people (males $=12$, mean age $=52)$ in 2020 committed suicide.

While official data for 2020 for the general Italian population are still unavailable, we could not adjust for potential confounders; we feel that the present information is worth reporting. Considering the small size of our sample, our records would excluded significant changes in suicide incidence rate within 2015-2020 (till December 2020). However, the COVID-19 pandemic spread faster in Italy than in other regions, meaning that the Italian State Police possibly faced prolonged, intense stress.

Although data indicating no significant increase in suicides in Queensland during 2020 compared to 20152019 annual records and suicide deaths declined by $5.6 \%$ from 2019 to 2020 in the US [8], confirmation is mandatory for the complex interactions between self-harm [9], suicide due to stressful events [10], mental health [11], and COVID-19 pandemic, especially considering the compelling need for high-quality studies already prompted-out by Stanley et al. [12].

From the beginning of the pandemic, a task force of international experts on suicide prevention started exploring the issue and provided some guidelines for confronting suicide risk during COVID-19 pandemic [3, 13]. It became clear that the pandemic's impact on suicide may have different pathways according to the different geographic areas and socio-cultural patterns. Overall, this problematic time produced a great deal of human misery [1]. During the 2008 economic crisis, there was a $12 \%$ increase in suicide deaths among Italian males aged 25-69, namely those in the labour market [14]. The COVID-19 pandemic closed down most commercial activities, and entire sectors of the economy now struggle to survive.

\section{Conclusion}

The worldwide COVID-19 pandemic and efforts to contain it represent a further threat, and we must recognize the pandemic of mental and behavioral illness that will quickly follow it, and implement the steps needed to mitigate it [2]. Suicide prevention remains a priority, especially during this difficult time [4]. Despite everything, it can be a source of opportunities if viewed in light of the efforts made to implement preventive measures [3, 15]. Such efforts should also be extended to different sub-populations that may have specific unmet needs, such as youths, elderly, or first-line responders that may impact life-threatening facing situations.

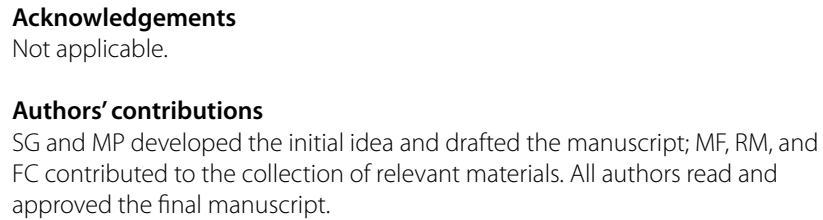

\section{Declarations}

Ethics approval and consent to participate

Not applicable.

Consent for publication

Not applicable.

\section{Competing interests}

The authors declare that they have no competing interests.

\section{Author details}

${ }^{1}$ State Police Health Service Department, Ministry of the Interior, 00198 Rome, Italy. ${ }^{2}$ Department of Neuroscience, Rehabilitation, Ophthalmology, Genetics and Maternal/Child Sciences (DINOGMI), University of Genoa, Genoa, Italy. ${ }^{3}$ Section of Psychiatry, Department of Neuroscience, University School of Medicine "Federico II," Naples, Italy. ${ }^{4}$ Department of Neurosciences, Mental Health and Sensory Organs, Suicide Prevention Center, Sant'Andrea Hospital, Sapienza University, 00185 Rome, Italy.

Received: 27 February 2021 Accepted: 30 April 2021

Published online: 07 May 2021

\section{References}

1. Ettman CK, Abdalla SM, Cohen GH, Sampson L, Vivier PM, Galea S. Prevalence of depression symptoms in US adults before and during the COVID-19 Pandemic. JAMA Netw Open. 2020;3(9):e2019686. https://doi. org/10.1001/jamanetworkopen.2020.19686.

2. Galea S, Merchant RM, Lurie N. The mental health consequences of COVID-19 and physical distancing: the need for prevention and early intervention. JAMA Intern Med. 2020;180(6):817-8. https://doi.org/10. 1001/jamainternmed.2020.1562.

3. Gunnell D, Appleby L, Arensman E, Hawton K, John A, Kapur N, Khan M, O'Connor RC, Pirkis J, COVID-19 Suicide Prevention Research Collaboration. Suicide risk and prevention during the COVID-19 pandemic. Lancet Psychiatry. 2020;7(6):468-71.

4. Pompili M. Suicide at the time of Covid-19. BMJ 2020; https:// blogs.bmj.com/bmj/2020/09/10/maurizio-pompili-suicide-preve ntion-at-the-time-of-covid-19/

5. John A, Pirkis J, Gunnell D, Appleby L, Morrissey J. Trends in suicide during the covid-19 pandemic. BMJ. 2020;371:m4352.

6. Leske S, Kõlves K, Crompton D, Arensman E, de Leo D. Real-time suicide mortality data from police reports in Queensland, Australia, during the COVID-19 pandemic: an interrupted time-series analysis. Lancet Psychiatry. 2021;8(1):58-63. https://doi.org/10.1016/S2215-0366(20)30435-1.

7. Sakamoto H, Ishikane M, Ghaznavi C, Ueda P. Assessment of suicide in Japan during the COVID-19 pandemic vs previous years. JAMA Netw 
Open. 2021;4(2):e2037378. https://doi.org/10.1001/jamanetworkopen. 2020.37378.

8. Ahmad FB, Anderson RN. The leading causes of death in the US for 2020 . JAMA. 2021. https://doi.org/10.1001/jama.2021.5469.

9. Kapur N, Clements C, Appleby L, Hawton K, Steeg S, Waters K, Webb R. Effects of the COVID-19 pandemic on self-harm. Lancet Psychiatry. 2021;8(2): 4 .

10. Brewer C. Covid-19 and suicide: lessons from the Blitz. Lancet Psychiatry, 2021; 8(2), e8.

11. Pfefferbaum B, North CS. Mental health and the Covid-19 pandemic. N Engl J Med. 2020;383(6):510-2.

12. Stanley IH, Hom MA, Joiner TE. A systematic review of suicidal thoughts and behaviors among police officers, firefighters, EMTs, and paramedics. Clin Psychol Rev. 2016;44:25-44.

13. Niederkrotenthaler T, Gunnell D, Arensman E, Pirkis J, Appleby L, Hawton K, John A, Kapur N, Khan M, O'Connor RC, Platt S; International COVID-19
Suicide Prevention Research Collaboration. Suicide research, prevention, and COVID-19. Crisis. 2020:41(5):321-30.

14. Pompili M, Vichi M, Innamorati M, Lester D, Yang B, De Leo D, Girardi P. Suicide in Italy during a time of economic recession: some recent data related to age and gender based on a nationwide register study. Health Soc Care Community. 2014;22(4):361-7.

15. Moutier C. Suicide prevention in the COVID-19 era: transforming threat into opportunity. JAMA Psychiat. 2020. https://doi.org/10.1001/jamap sychiatry.2020.3746.

\section{Publisher's Note}

Springer Nature remains neutral with regard to jurisdictional claims in published maps and institutional affiliations.
Ready to submit your research? Choose BMC and benefit from:

- fast, convenient online submission

- thorough peer review by experienced researchers in your field

- rapid publication on acceptance

- support for research data, including large and complex data types

- gold Open Access which fosters wider collaboration and increased citations

- maximum visibility for your research: over $100 \mathrm{M}$ website views per year

At BMC, research is always in progress.

Learn more biomedcentral.com/submissions 